\title{
Land Capability and Land Irrigability Classification in Garakahalli Micro- watershed of Karnataka
}

\author{
S.C. Ramesh Kumar, B.P. Bhaskar, M. Chandrakala*, K.V. Niranjana, \\ Rajendra Hegde and S.K. Singh \\ National Bureau of Soil Survey and Land Use Planning, Regional Centre, \\ Bengaluru-560024, Karnataka, India
}

\begin{abstract}
Land suitability for irrigation in semi-arid regions is important for agricultural development and to overcome water scarcity. The detailed soil survey of Garakahalli micro- watershed (447 ha) of Karnataka was carried out and mapped into 85 mapping units. The soil units were evaluated for surface irrigation. The suitability maps showed 74.06 per cent arable land, out of which 69.19 per cent of land is suitable for surface irrigation and remaining is unsuitable due to the limitation of the topography and stoniness. The detailed land resource data base in association with GIS and remote sensing was highly efficient in modeling and developing land suitability maps which can be used as a planning tool to optimize the agriculture in semi-arid regions of Karnataka.
\end{abstract}

Keywords: Land evaluation, irrigability, capability, micro-watershed

\section{Introduction}

The utilization of land and water resources are the major concern in arid and semi-arid regions covering more than 60 per cent of area in the country. Over 75 per cent of the cropped area falls in the semiarid tropical region. Most of these drought prone districts are concentrated in Andhra Pradesh, Maharashtra, Tamil Nadu, Karnataka and Rajasthan, affecting 265 million people. Management of soil resources on scientific principles is essential to maintain the present level of soil productivity and to prevent its degradation. Therefore, in recent years increasing emphasis is laid on characterization of soils, accurate mapping of soils and developing rational and scientific criteria for land evaluation for its multifarious uses. This calls for a comprehensive knowledge on soil resources

*Corresponding author: (Email: chandra.ssac@gmail.com) in terms of types of soils, their spatial extent, physical and chemical properties and limitations / capabilities. This kind of exercise using land capability and irrigability classification have been reported by researchers including Mani Bhushan and Roy (2018), but it is lacking in typical micro-watershed representing semi-arid tract of dry zone of Karnataka. Thus the present study was undertaken with the objective of generating soil resource information on 1:10000 scale for deriving land capability/ irrigability groupings for proper utilization of land resources, where irrigation potential is low.

\section{Materials and Methods}

Studyarea

Garakahalli micro-watershed (527 ha) lies between $12^{\circ} 31^{\prime} 15^{\prime \prime}$ to $12^{\circ} 31^{\prime} 36^{\prime \prime} \mathrm{N}$ latitude and $77^{\circ} 7^{\prime} 5^{\prime \prime}$ to 7707'54" E longitude (Fig.1). Garakahalli micro- 
watershed comes under agro-climatic zone 5 (eastern dry zone) of Karnataka. Garakahalli area receives a mean annual rainfall of $821.0 \mathrm{~mm}$ with bimodal distribution. May and September are the peak rainy months with length of the growing period of 120 to 150 days (August to November). The frequency of drought is 1 to 2 in a decade. The mean maximum temperature during July to November is 26.3 to $27.6^{\circ} \mathrm{C}$ and mean minimum temperature of 17.2 to $19.2 \mathrm{C}$. The geology of study area is granite and granite-gneiss having very gently sloping to gently sloping lands at an elevation of $895 \mathrm{~m}$ to $900 \mathrm{~m}$ above MSL. The major area of the micro-watershed is under rainfed crops like groundnut (Arachis hypogaea), finger millet (Eleusine coracana), horse gram (Macrotyloma uniflorum) and sorghum (Sorghum bicolur). Irrigation from tubewells has enabled cultivation of irrigated mulberry (Morus indica), banana (Musa acuminata colla) and rice (Oryza sativa) in some patches of the watershed. The natural vegetation consists of Ficus spp., Accacia arabica, Azadirachta indica, Eucalyptus globulus, Tamarindus indica, and Pongamia glabra.

\section{Field survey}

A detailed soil survey of the Garakahalli microwatershed was carried out using cadastral map to 1:4560 scale in conjunction with the False Colour Composite (FCC) of IRS - P6 -LISS IV satellite imagery Plus cartosat -1 merged data to identify landforms, land use and land cover following standard procedures. Eleven soil series were identified after field correlation and classified upto family level as per Soil Survey Staff (2014). The soil map was generated using Arc GIS 10.3 software. The land capability maps were prepared as per the guidelines of Klingebiel and Montgomery (1966). The land irrigability map was generated as per the guidelines proposed by Sehgal (1996). The step-wise methodology adopted in this study is given in figure 2 . Horizon-wise soil samples were collected from representative pedon of each series, processed and analysed as per standard procedures (Jackson 1973).

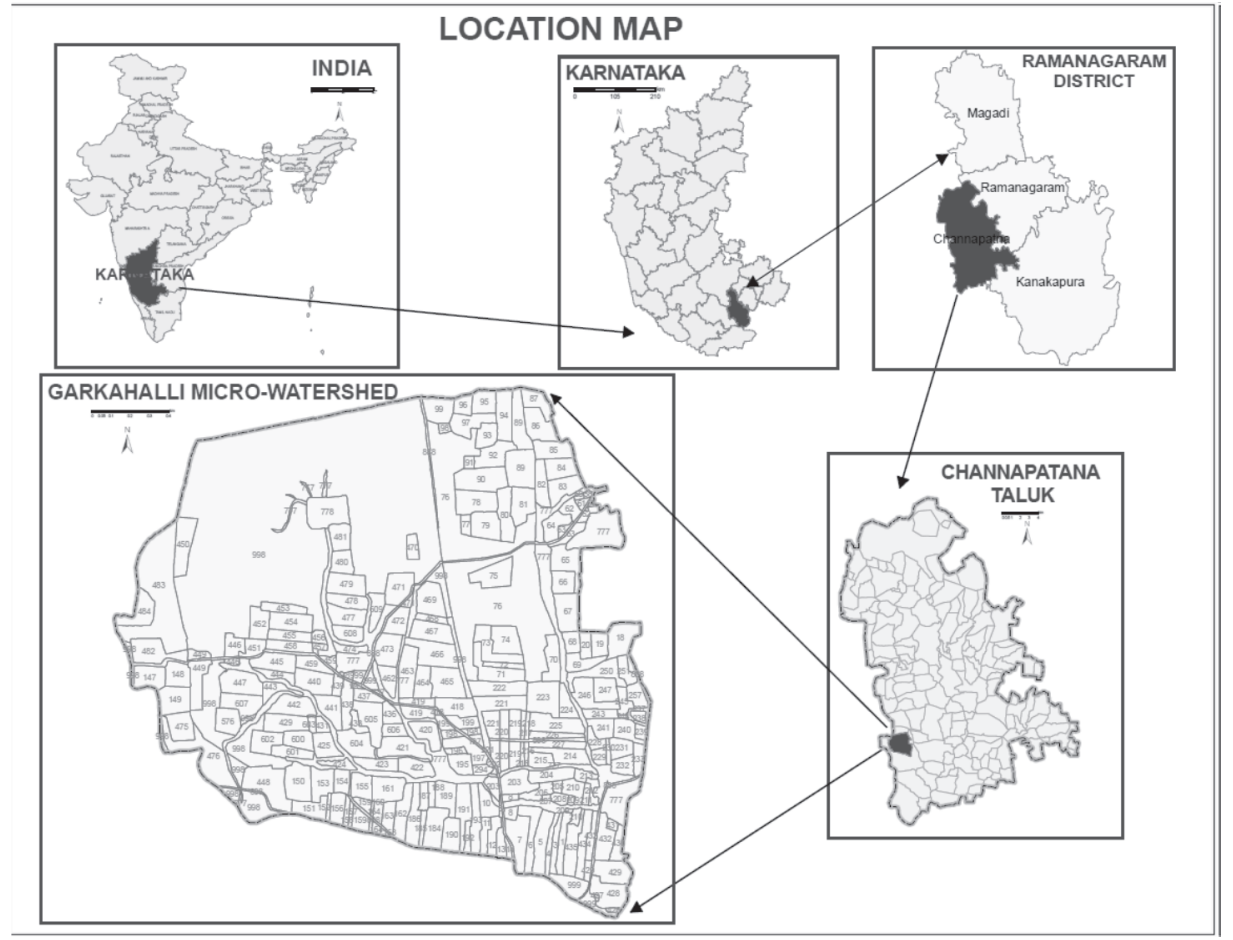

Fig. 1. Location map of study area 


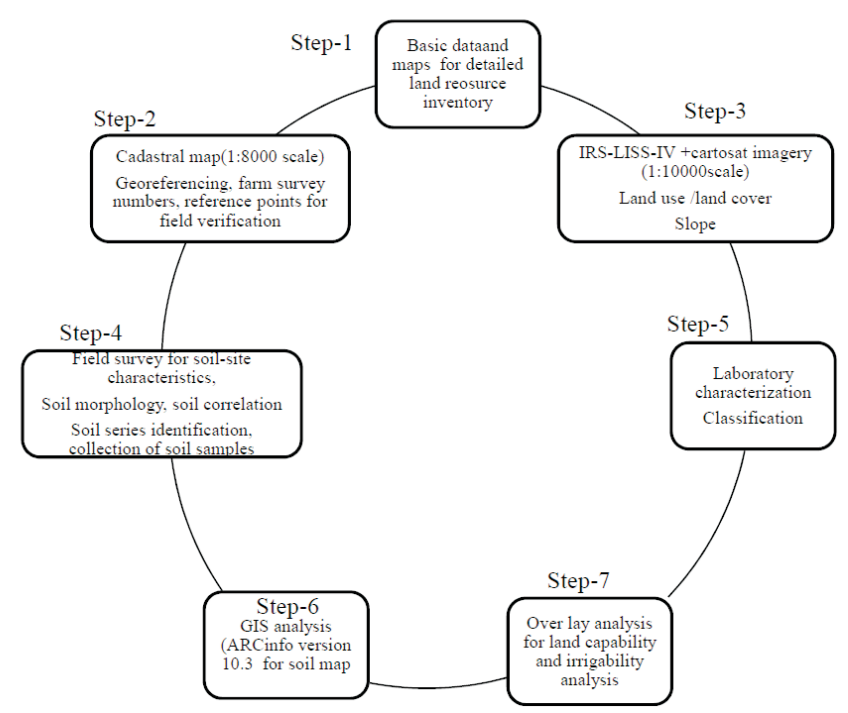

Fig.2. Step wise methodology used in Garakahalli microwatershed

\section{Results and Discussion}

Physical and chemical characteristics of soils

The soils (Lithic Ustorthent) are very shallow ( $<25 \mathrm{~cm}$ deep), well drained, dark brown to dark reddish brown, gravelly sandy loam (17.8\% clay) with more than 1 per cent of organic carbon and 60 to 70 per cent gravels and stones. These soils are slightly acid (pH 6.3) with cation exchange capacity of $7.0 \mathrm{cmol}(\mathrm{p}+) \mathrm{kg}^{-1}$ and base saturation of 86 per cent (Table 1 ).

Typic Rhodustalfs covers an area of 30.68 per cent of TGA of watershed. These soils have A horizon with dark brown to dark reddish brown colour, sandy loam to sandy clay loam texture but gradually changed to dark reddish brown and gravelly sandy clay loam to sandy clay in argillic horizons (Table 1). These soils occur on very gently sloping to gently sloping (1-8\% slope) uplands and are cultivated to kharif crops. The soils are slightly acid to neutral (pH 6.4-6.9). Clay content is 19.2 per cent in the surface soil and 24.5-31.6 per cent in the sub-soil. Cation exchange capacity is 6.0 cmol $(\mathrm{p}+) \mathrm{kg}^{-1}$ to $17.1 \mathrm{cmol}(\mathrm{p}+) \mathrm{kg}^{-1}$ with base saturation more than 60 per cent. Organic carbon content $(0.24 \%)$ is low. The soil types that classified under this subgroup are B, C, D, F, G, I and L.

Under Typic Haplustalfs, three soil types namely E, J and M cover an area of 6.16 per cent of watershed.
These soils are moderately deep with reddish brown to red and dark red, sandy clay loam with $15-35$ per cent gravels mainly of quartz in the sub-soil. These soils occur on very gently sloping to gently sloping (1-8\% slope) uplands and are slightly eroded. These soils are slightly acid ( $\mathrm{pH}$ 6.4) to neutral ( $\mathrm{pH}$ 6.4-7.1) with 23.2 per cent of clay in A horizons and 31.3 per cent clay in Bt horizons. The cation exchange capacity for surface horizons is $10.1 \mathrm{cmol}(\mathrm{p}+) \mathrm{kg}^{-1}$ and increased up to 11.6 cmol $(\mathrm{p}+) \mathrm{kg}^{-1}$ in the sub-soil horizons. The base saturation ranged from 51 to 61 per cent in the sub- soil. Organic carbon content (0.31\%) is low.

Soil type $\mathrm{K}$ is classified as Rhodic Paleustalfs and cover an area of 27.76 per cent. These soils are very deep $(>150 \mathrm{~cm})$ and well drained. These soils have dark brown, sandy loam to sandy clay loam texture with low organic carbon in A horizons and dark red to dark reddish brown, sandy clay loam to gravelly sandy clay texture in Bt horizons. These soil soccur on very gently sloping to moderately sloping ( $1-15 \%$ slope) uplands and cultivated to rainfed kharif crops. These soils had $\mathrm{pH}$ ranging From ( $\mathrm{pH}$ 5.9-6.9). Clay content is 13.5 per cent in A horizons but varied from 32.3-42.0 per cent in the sub-soils. The cation exchange capacity of Bt horizons ranged from is 13.5 to $18.0 \mathrm{cmol}(\mathrm{p}+) \mathrm{kg}^{-1}$ with base saturation less than 60 per cent. 
The soil type $\mathrm{H}$ is classified as Kandic Paleustalfs and covers 9.22 per cent area in the watershed. These soils are deep $(100-150 \mathrm{~cm})$ and well drained. The A horizons are dark brown to red with loamy sand texture but changed to dark red to dark reddish brown, gravelly sandy clay loam and gravelly sandy clay sub-soils with 15-60 per cent quartz gravel. They occur on very gently sloping to moderately sloping (1-15\% slope) uplands and are cultivated to rainfed crops. The soils had $\mathrm{pH}$ ranging from $\mathrm{pH} 5.8$ to 6.7. Clay content is 21.5 per cent in the surface but increased to 41.9 per cent in Bt horizons. The sub soils have cation exchange capacity of 8.3-16.6 $\mathrm{cmol}(\mathrm{p}+) \mathrm{kg}^{-1}$ and base saturation of 48 to 93 per cent. Organic carbon content $(0.50 \%)$ is low.

Soil type N (Fluventic Haplustepts) is deep and well drained. The A horizons have reddish brown to dark reddish brown in colour with loamy sand to sandy loam textures but changed to yellowish red to dark reddish brown and dark red, gravelly sandy loam to sand and sandy clay loam indicating textural variations in sub-soils. These soils are alkaline (pH 7.5) with clay content of 25.6 per cent in A horizons but shows irregular distribution with depth. These soils had low cation exchange capacity, decreasing irregularly (2.0$\left.5.9 \mathrm{cmol}(\mathrm{p}+) \mathrm{kg}^{-1}\right)$ in the sub-soil with a base saturation of 50 to 60 per cent. Organic carbon content $(0.43 \%)$ is low.

\section{Soilmap}

The soil map is generated with 14 soil types and 85 management units based on surface texture, slope and erosion under ARC info environment (Fig. 3). The soil mapping units for soil A is defined as Ag2hD2St4 having gravelly sandy clay loam surface, moderately slopy and moderately eroded and very stony. This unit covers 0.39 per cent of total area of watershed. Among 85 units, the soil type K has 14 units $(27.76 \%, 146.38$ ha) and 15 units for soil type $H$ and cover 48.59 ha $(9.22 \%$ of area). Likewise Soil $\mathrm{G}$ has 10 units cover 27.03 ha (5.13\%) while soil $\mathrm{C}$ with 8 units covers 9.61 per cent of area. The Soil type B, L and M have 2 units each but cover an area less than 3 per cent of total area.

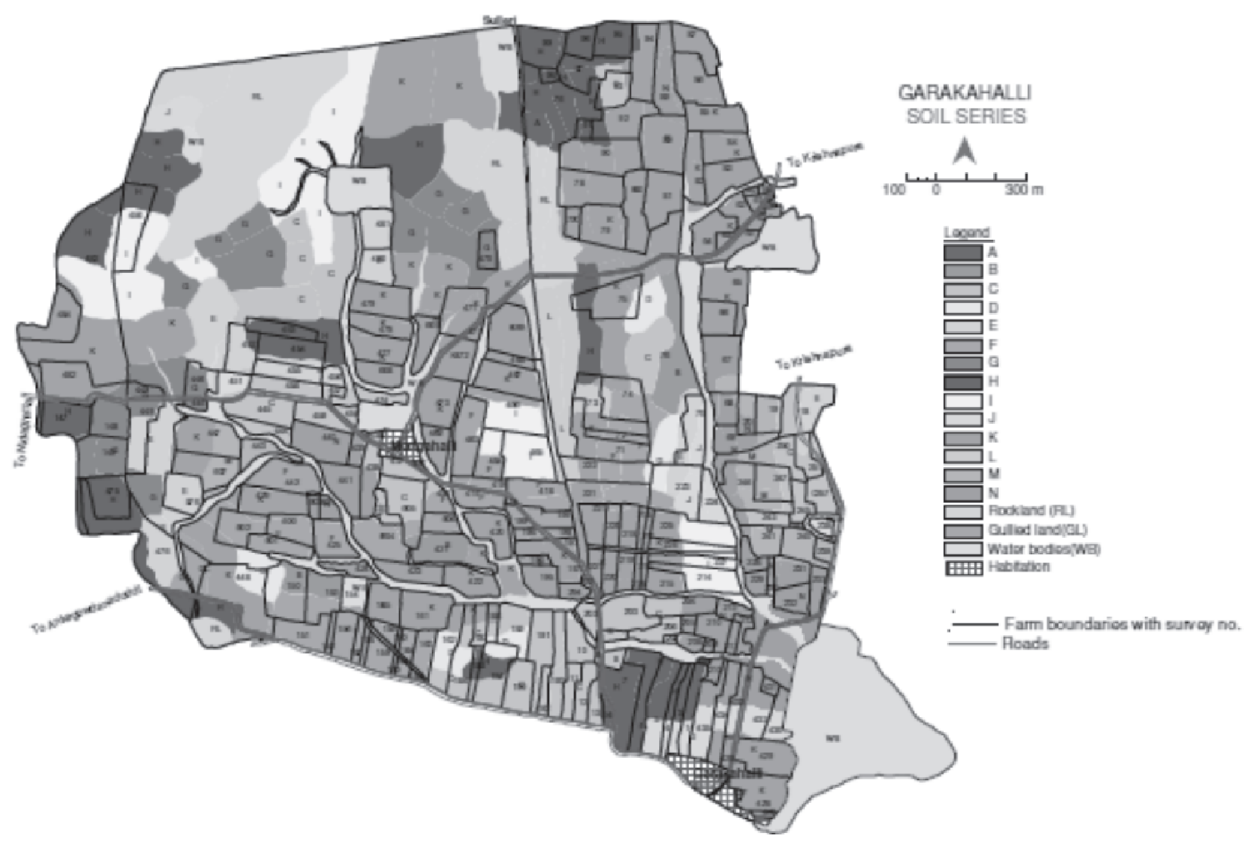

Fig. 3. Soils type map of Garakahalli microwatershed 
Table 1. Physical and chemical properties of the soils of Garakahalli microwatershed

\begin{tabular}{|c|c|c|c|c|c|c|c|c|c|c|c|c|}
\hline \multirow[t]{2}{*}{$\begin{array}{c}\text { Hori- } \\
\text { zon }\end{array}$} & \multirow[t]{2}{*}{$\begin{array}{l}\text { Depth } \\
\text { cm }\end{array}$} & \multicolumn{3}{|c|}{$\begin{array}{c}\text { Particle size } \\
\text { distribution } \\
(\% \text { of }<2 \mathrm{~mm})\end{array}$} & \multirow[t]{2}{*}{$\begin{array}{c}\text { Organic } \\
\text { Carbon } \\
(\%)\end{array}$} & \multirow[t]{2}{*}{$\mathbf{p H}$} & \multicolumn{4}{|c|}{$\begin{array}{l}\text { Exchangeable bases } \\
\quad\left(\mathrm{cmol}\left(\mathrm{p}^{+}\right) \mathrm{kg}^{-1}\right)\end{array}$} & \multirow[t]{2}{*}{ CEC } & \multirow[t]{2}{*}{$\begin{array}{c}\text { Base } \\
\text { saturation } \\
(\%)\end{array}$} \\
\hline & & Sand & Silt & Clay & & & $\mathrm{Ca}$ & $\mathrm{Mg}$ & $\mathrm{Na}$ & $\mathrm{K}$ & & \\
\hline \multicolumn{13}{|c|}{ Soil type A. : Loamy-skeletal, mixed, isohyperthermic Lithic Ustorthents } \\
\hline $\mathrm{A}$ & $0-14$ & 64.7 & 13.1 & 22.2 & 1.21 & 6.3 & 2.9 & 2.5 & 0.0 & 0.6 & 7.0 & 59 \\
\hline \multicolumn{13}{|c|}{ Soil type B : Fine, mixed, isohyperthermic, Typic Rhodustalfs } \\
\hline Ap & $0-18$ & 65.1 & 7.9 & 27.0 & 0.37 & 6.8 & 5.1 & 1.8 & 0.0 & 0.2 & 9.9 & 72 \\
\hline Bt1 & $18-42$ & 46.0 & 12.4 & 41.6 & 0.83 & 7.1 & 10.3 & 2.1 & 0.1 & 0.1 & 16.8 & 75 \\
\hline $\mathrm{Bt} 2$ & $42-75$ & 61.6 & 12.3 & 26.1 & 0.21 & 7.5 & 7.8 & 1.3 & 0.1 & 0.1 & 12.2 & 76 \\
\hline \multicolumn{13}{|c|}{ Soil type C : Fine, mixed, isohyperthermic Typic Rhodustalfs } \\
\hline Ap & $0-13$ & 70.3 & 13.1 & 16.6 & 0.19 & 6.8 & 6.5 & 1.7 & 0 & 0.1 & 10.3 & 81 \\
\hline Bt1 & $13-40$ & 49.3 & 15.6 & 35.1 & 0.32 & 6.5 & 10.9 & 3.8 & 0.1 & 0.1 & 18.3 & 81 \\
\hline Bt2 & $40-58$ & 40.3 & 19.7 & 40.0 & 0.42 & 6.6 & 10.8 & 4.4 & 0 & 0.1 & 19.0 & 81 \\
\hline $\mathrm{Bt} 3$ & $58-83$ & 77.3 & 14.5 & 8.2 & 0.11 & 8.3 & & & & & & \\
\hline \multicolumn{13}{|c|}{ Soil type D: Fine, mixed, isohyperthermic Typic Rhodustalfs } \\
\hline $\mathrm{Ap}$ & 0-14 & 56.9 & 10.6 & $32.5^{\circ}$ & 0.45 & 7.3 & 6.4 & 1.8 & 0.5 & 0.2 & 13.2 & 67 \\
\hline Bt1 & $14-37$ & 26.9 & 29.3 & 43.8 & 0.32 & 7.3 & 7.0 & 2.0 & 0.4 & 0.1 & 15.6 & 61 \\
\hline $2 \mathrm{Bt} 2$ & $37-63$ & 43.5 & 14.9 & 41.6 & 0.26 & 7.2 & 7.7 & 2.1 & 0.9 & 0.1 & 16.8 & 64 \\
\hline $3 \mathrm{Bt} 3$ & 63-89 & 44.0 & 17.4 & 38.6 & 0.24 & 7.2 & 8.0 & 2.0 & 0.9 & 0.1 & 17.1 & 64 \\
\hline \multicolumn{13}{|c|}{ Soil type E: Fine-loamy, mixed, isohyperthermic Typic Haplustalfs } \\
\hline Ap & $0-7$ & 60.6 & 16.2 & 23.2 & 0.31 & 6.4 & 4.8 & 4.4 & 0.1 & 0.1 & 10.1 & 53 \\
\hline Bt1 & $7-30$ & 59.4 & 12.2 & 28.4 & 0.30 & 6.8 & 4.6 & 4.4 & 0.1 & 0.1 & 10.0 & 52 \\
\hline Bt2 & $30-51$ & 55.8 & 12.9 & 31.3 & 0.31 & 6.8 & 6.3 & 4.4 & 0.3 & 0.1 & 11.6 & 61 \\
\hline $\mathrm{Bt} 3$ & $51-72$ & 61 & 14.2 & 24.8 & 0.19 & 7.0 & 5.5 & 4.4 & 0.3 & 0.1 & 11.1 & 57 \\
\hline Bt4 & 72-96 & 67.2 & 13.7 & 19.1 & 0.24 & 7.1 & 4.3 & 0.3 & 0.2 & 0.1 & 9.6 & 51 \\
\hline \multicolumn{13}{|c|}{ Soil type F : Fine, mixed, isohyperthermic Typi c Rhodustalfs } \\
\hline Ap & $0-15$ & 47.3 & 18.5 & $34.2^{\circ}$ & 0.28 & 6.3 & 2.0 & 0.4 & 0.4 & 0.1 & 3.6 & 81 \\
\hline Bt1 & $15-52$ & 49.6 & 9.4 & 41.0 & 0.38 & 6.9 & 5.1 & 0.8 & 0.5 & 0.1 & 11.5 & 57 \\
\hline $\mathrm{Bt} 2$ & $52-75$ & 47.4 & 10.5 & 42.1 & 0.39 & 6.7 & 5.6 & 0.9 & 0.4 & 0.1 & 12.1 & 58 \\
\hline $2 \mathrm{Bt} 3$ & $75-106$ & 45.5 & 7.9 & 46.6 & 0.25 & 6.4 & 6.0 & 0.9 & 0.6 & 0.1 & 12.9 & 59 \\
\hline 2Bt4 & $106-130$ & 56.5 & 11.7 & 31.8 & 0.18 & 6.5 & 5.6 & 0.7 & 0.5 & 0.1 & 10.9 & 63 \\
\hline \multicolumn{13}{|c|}{ Soil type G : Fine-loamy, mixed, isohyperthermic Typic Rhodustalfs } \\
\hline $\mathrm{A}$ & $0-16$ & 79.3 & 10.5 & 10.2 & 0.76 & 6.2 & 2.7 & 1.7 & 0 & 0.4 & 7.0 & 69 \\
\hline Bt1 & $16-48$ & 58.9 & 13.9 & 27.2 & 0.50 & 6.4 & 3.8 & 2.1 & 0 & 0.1 & 9.0 & 67 \\
\hline Bt2 & $48-84$ & 64.9 & 15.5 & 19.6 & 0.28 & 6.6 & 4.7 & 2.7 & 0 & 0.1 & 7.5 & 100 \\
\hline $\mathrm{Bt} 3$ & 84-106 & 77.3 & 17.7 & 5.0 & 0.14 & 6.7 & 5.0 & 2.8 & 0 & 0.1 & 8.0 & 99 \\
\hline \multicolumn{13}{|c|}{ Soil type H : Clayey-skeletal, mixed, isohyperthermic Kandic Paleustalfs } \\
\hline Ap & $0-10$ & 69.9 & 8.6 & 21.5 & 0.50 & 5.9 & 2.3 & 0.4 & 0.4 & 0.1 & 6.3 & 51 \\
\hline Bt1 & $10-29$ & 60.1 & 8.9 & 31.0 & 0.43 & 5.8 & 3.3 & 0.4 & 0.5 & 0.1 & 8.3 & 52 \\
\hline $2 \mathrm{Bt} 2$ & $29-45$ & 50.7 & 9.0 & 40.3 & 0.48 & 6.3 & 4.0 & 0.5 & 0.5 & 0.1 & 10.1 & 50 \\
\hline $2 \mathrm{Bt} 3$ & $45-84$ & 48.3 & 9.8 & 41.9 & 0.33 & 6.7 & 3.2 & 5.3 & 0.2 & 0.1 & 9.5 & 93 \\
\hline $2 \mathrm{Bt} 4$ & $84-122$ & 45.9 & 14.5 & 39.6 & 0.28 & 6.3 & 5.0 & 0.5 & 0.2 & 0.1 & 12.2 & 48 \\
\hline $2 \mathrm{Bt} 5$ & $122-144$ & 49.2 & 16.1 & 34.7 & 0.25 & 6.6 & 8.5 & 1.1 & 0.3 & 0.1 & 16.6 & 60 \\
\hline \multicolumn{13}{|c|}{ Soil type I: Fine, mixed, isohyperthermic Typic Rhodustalfs } \\
\hline $\mathrm{Ap}$ & 0-10 & 73.1 & 7.7 & 19.2 & 0.24 & 6.5 & 2.3 & 1.7 & 0 & 0.3 & 6.0 & 72 \\
\hline Bt2 & $10-44$ & 49.4 & 26.1 & 24.5 & 0.32 & 6.4 & 5.6 & 3.7 & 0.1 & 0.1 & 11.5 & 83 \\
\hline Bt1 & $44-77$ & 51.6 & 16.8 & 31.6 & 0.37 & 6.0 & 3.8 & 2.9 & 0 & 0.2 & 9.6 & 72 \\
\hline Bt3 & $77-109$ & 47.4 & 21.7 & 30.9 & 0.30 & 6.8 & 6.9 & 4.0 & 0.1 & 0.1 & 11.9 & 93 \\
\hline Bt4 & $109-130$ & 50.4 & 39.8 & 9.8 & 0.36 & 6.9 & 5.5 & 3.2 & 0 & 0.1 & 10.7 & 82 \\
\hline
\end{tabular}




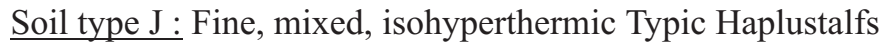

$\begin{array}{lrrrrrrrrrrrr}\text { Bt1 } & 0-12 & 67.6 & 15.5 & 16.9 & 0.46 & 8.2 & 5.9 & 3.4 & 0.2 & 0.2 & 10.5 & 92 \\ \text { Ap } & 12-33 & 64.9 & 13.4 & 21.7 & 0.53 & 8.3 & 5.3 & 2.9 & 0.2 & 0.2 & 9.4 & 91 \\ \text { Bt2 } & 33-60 & 49.5 & 9.6 & 40.9 & 0.34 & 8.2 & 8.3 & 4.6 & 0.4 & 0.1 & 15.1 & 89 \\ \text { Bt3 } & 60-94 & 48.5 & 11.6 & 39.9 & 0.38 & 8.2 & 9.2 & 4.6 & 0.4 & 0.1 & 16.8 & 85 \\ \text { Bt4 } & 94-130 & 47.0 & 19.2 & 33.8 & 0.17 & 8.1 & 8.2 & 4.0 & 0.5 & 0.1 & 14.2 & 90\end{array}$

Soil type K: Fine, mixed, isohyperthermic Rhodic Paleustalfs

$\begin{array}{lcrrrrrrrrrrr}\text { Ap } & 0-10 & 79.1 & 7.4 & 13.5 & 0.41 & 5.9 & 2.2 & 0.3 & 0.1 & 0.1 & 5.5 & 49 \\ \text { Bt1 } & 10-40 & 50.0 & 17.7 & 32.3 & 0.39 & 6.7 & 6.2 & 0.5 & 0.3 & 0.1 & 13.5 & 53 \\ \text { Bt2 } & 40-69 & 45.6 & 12.4 & 42.0 & 0.50 & 6.8 & 6.1 & 0.5 & 0.3 & 0.1 & 13.4 & 52 \\ \text { Bt3 } & 69-98 & 48.4 & 11.0 & 40.6 & 0.65 & 6.4 & 5.4 & 0.4 & 0.2 & 0.1 & 12.9 & 47 \\ \text { 2Bt4 } & 98-133 & 50.6 & 14.5 & 34.9 & 0.32 & 6.9 & 6.3 & 0.5 & 0.3 & 0.1 & 13.8 & 52 \\ \text { 3Bt5 } & 133-151 & 44.0 & 20.9 & 35.1 & 0.28 & 6.8 & 9.2 & 0.5 & 0.3 & 0.1 & 18.0 & 56\end{array}$

Soil type L : Loamy-skeletal, mixed, isohyperthermic Typic Rhodustalfs

$\begin{array}{ccccccccccccc}\text { Ap } & 0-8 & 74.7 & 12.8 & 12.5 & 0.37 & 6 & 3.1 & 0.5 & 0.3 & 0.1 & 7.1 & 56 \\ \text { Bt1 } & 8-25 & 55.5 & 15.4 & 29.1 & 0.49 & 6.2 & 7.5 & 1.2 & 0.4 & 0.1 & 13.9 & 66 \\ \text { Bt2 } & 25-56 & 51.6 & 12.1 & 36.3 & 0.38 & 7.0 & 9.0 & 1.4 & 0.4 & 0.1 & 15.4 & 71 \\ \text { Bt3 } & 56-79 & 45.1 & 9.0 & 45.9 & 0.44 & 7.6 & 9.6 & 1.2 & 0.5 & 0.1 & 16.5 & 69\end{array}$

$\underline{\text { Soil type M : Fine, mixed, isohyperthermic Typic Haplustalfs }}$

$\begin{array}{ccccccccccccc}\text { Ap } & 0-14 & 73.6 & 13.5 & 12.9 & 0.53 & 6.6 & 5.3 & 1.8 & 0.4 & 0.1 & 7.7 & 99 \\ \text { Bt1 } & 14-28 & 74.1 & 14.6 & 7.3 & 0.43 & 7.2 & 5.9 & 1.4 & 0.3 & 0.1 & 7.1 & 100 \\ \text { Bt2 } & 28-53 & 71.6 & 11.4 & 17.0 & 0.13 & 7.8 & 5.6 & 1.8 & 0.3 & 0.1 & 7.9 & 100\end{array}$

Soil type N : Coarse-loamy, mixed, isohyperthermic Fluventic Haplustepts

$\begin{array}{lccllllllllll}\text { Ap } & 0-11 & 61.2 & 13.2 & 25.6 & 0.43 & 7.5 & 5.5 & 0.6 & 0.4 & 0.5 & 12.3 & 57 \\ \mathrm{Bw} & 11-30 & 73.6 & 10.4 & 16.0 & 0.37 & 7.5 & 3.5 & 0.5 & 0.3 & 0.2 & 9.0 & 50 \\ \mathrm{C} & 30-52 & 94.5 & 2.4 & 3.1 & 0.10 & 7.8 & 0.9 & 0.2 & 0.1 & 0 & 2.0 & 60 \\ \text { 2Bw } & 52-86 & 81.1 & 7.7 & 11.2 & 0.11 & 8.0 & 2.8 & 0.2 & 0.2 & 0.1 & 5.9 & 58\end{array}$

Land capability and land irrigability classification

The overlay analysis for capability and irrigability was performed as per the logical framework (Table 2).

The results showed that the watershed has 13 land capability units identified under five land capability classes (Fig. 4). Among arable classes, the capability class II lands occupy 338.79 ha i.e. 68.19 per cent TGA of watershed. It was further classified into three capability units such as IISt9 (minor problems of low fertility and heavy-textured surface soil); IIst9 cover 234.57 ha (44.49\% of TGA), IIS2 (problem of coarsetextured surface soil (71.48 ha, 13.56\%); IIs3: problem of heavy-textured surface soil (32.74 ha, 6.21\%). They occur on very gently sloping to gently sloping (1-5\% slope) uplands and require contour bunds with open ends or waste weirs, graded bunds and graded or contour border strips. These soils are grouped as suitable for irrigation but topographic limitations in 9 soil units covering 29.94 ha and thus categorized as 2 st irrigability sub-class.

Land capability class III are moderately good cultivable lands with problems of surface stoniness (IIIs0, $10.38 \mathrm{ha}$ ). These soils are moderately deep or deep $(75-150 \mathrm{~cm})$, with sand to sandy clay and clayey sub-soils. The soil mapping units grouped under this capability units are Dg1bB1St3, Eg1cB1St3, Gg1hC1St3, HcB1St3 and HmC1St3. 
The soils grouped under land capability class IIIs 8 are slightly deep $(50-75 \mathrm{~cm})$, sandy loam or sandy clay loam surface soils occuring on very gently sloping (1-3\% slope) uplands. This unit covers 7.35 ha (1.39 per cent) and has only two units, (BcB1 and BmB1). These soil units are very susceptible to sheet and rill erosion that needs contour bunds or contour border strips. Short duration crops can be grown.

The soils grouped under this land capability class (IIIes) are deep and very deep (100-150 cm) with loamy sand to sandy clay loam soils. These classes occupy an area of 20.22 ha (3.83\%) and occur on gently sloping (3-5\% slope) uplands and have problems of water erosion, gravelliness, and surface stoniness (3$15 \%$ ) stones). The soil map units grouped under this unit are $\mathrm{Gg} 2 \mathrm{hC} 2 \mathrm{St} 3, \mathrm{Ig} 2 \mathrm{hC} 2 \mathrm{St} 3$ and $\mathrm{Lg} 1 \mathrm{bC} 2 \mathrm{St} 3$. These units need intensive soil and water conservation measures like terracing, stone pitched contour bunds and graded border strips.

The soils grouped under IIIes2 (GbB2 and $\mathrm{KbC} 2)$ are deep to very deep $\left(100-150^{+} \mathrm{cm}\right)$, and have loamy sand, sandy loam and sandy clay loam texture. They occur on gently sloping (3-5\% slope) uplands and cover 7.78 ha $(1.48 \%)$ and suggested conservation measures are terracing, stone pitched contour bunds and graded border strips. These are non- irrigable and classified as $4 \mathrm{~s}$ and 4 st. These units are marginally suitable under irrigation due to soil and topography constraints. Limitations include stoniness/ gravelliness or coarse and heavy textures, permeability, available water capacity and slope.

Land capability class IV is fairly good for cultivation with moderate slope $(5-10 \%)$ and water erosion. The soil unit grouped under capability unit of IVe1 is KhD2 (6.78 ha, 1.29\%). These soils are very deep $(>150 \mathrm{~cm})$, sandy clay loam to gravelly sandy clay subsoils. They occur on moderately sloping (5-10\% slope) uplands and suggested for graded bunds and graded trenches. These marginal lands are suitable for occasional cultivation of short and medium duration crops and are better suited to silvipasture, agri-hortisilvipasture and agroforestry.

The soils grouped under capability unit of IVes are very shallow $(<25 \mathrm{~cm})$, moderately deep and deep $(75-150 \mathrm{~cm})$ with sandy loam to stony surface and clayey sub- soils. These soils occur on moderately sloping (5$10 \%$ slope) uplands and are very susceptible to water erosion. The soil map units grouped under this land capability unit are Ag2hD2St4, Eg2cC2St4, Hg1cD2St4, Hg1hD2St4, Hg2cD2St3, Hg2hD2St4, Jg1hD2St3, $\mathrm{KhD} 2 \mathrm{St} 3$ and $\mathrm{Lg} 1 \mathrm{cD} 2 \mathrm{St} 3$. These unit covers 27.43 ha (5.2\% of area) and needs soil and water conservation measures like graded bunds with grassed waterways and graded trenches. These units are well suited for agrihorti-silvipasture, pasture, silvipasture and agroforestry.

\section{Non-arable land}

The watershed has 70.77 ha (13.34\% of area) land under non-arable class with severe erosion and surface stoniness. These soils are deep (100-150 cm), gravelly with stony surface soils and gravelly sandy clay loam sub-soils. These lands are suitable for forestry, agro-forestry, pasture and silvi-pasture. The soil mapping units grouped under this unit are Gg1cE3St4 and Gg1hE3St4. This class also includes miscellaneous lands with high grade export quality granite sheet rock. 


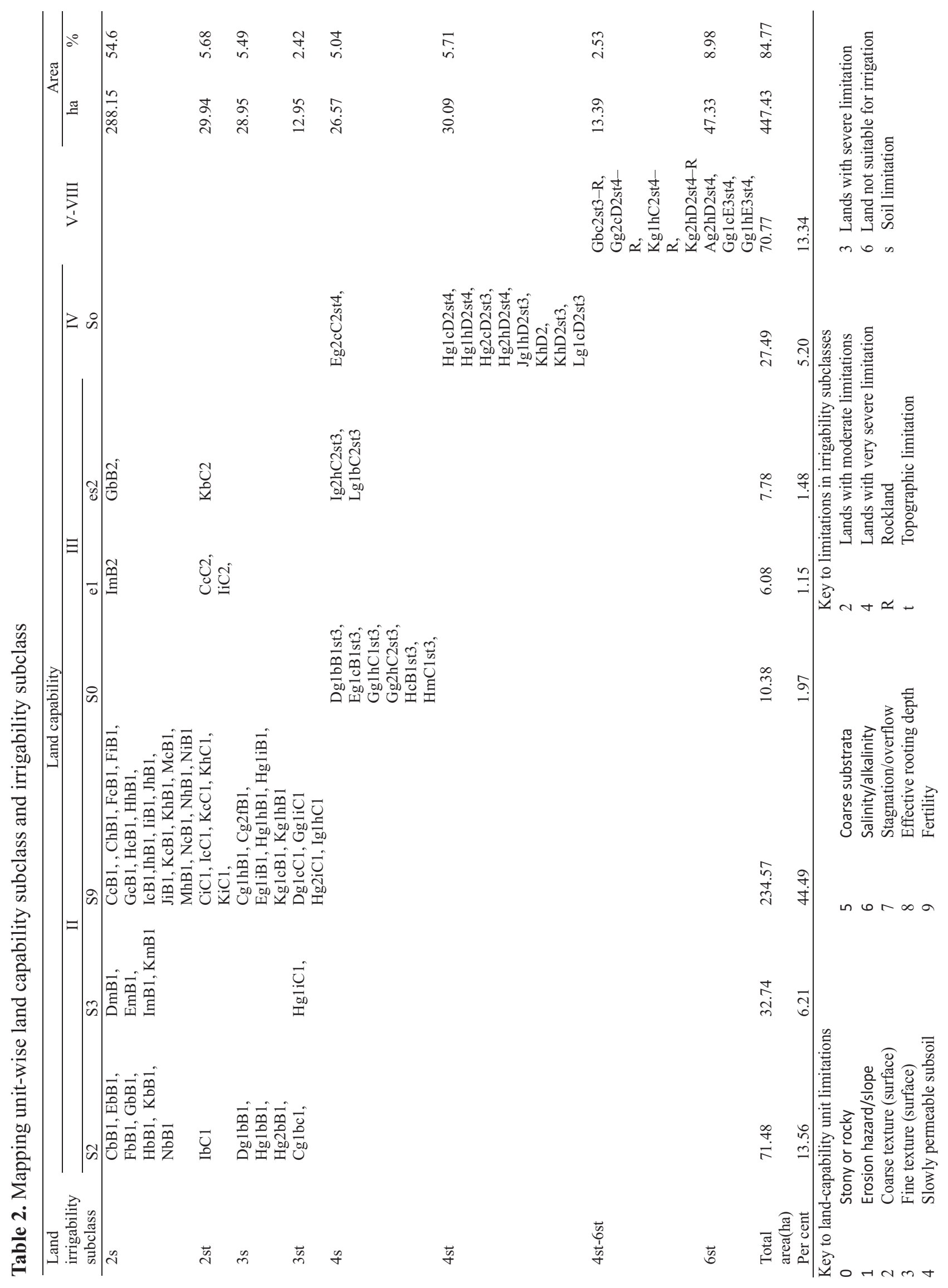




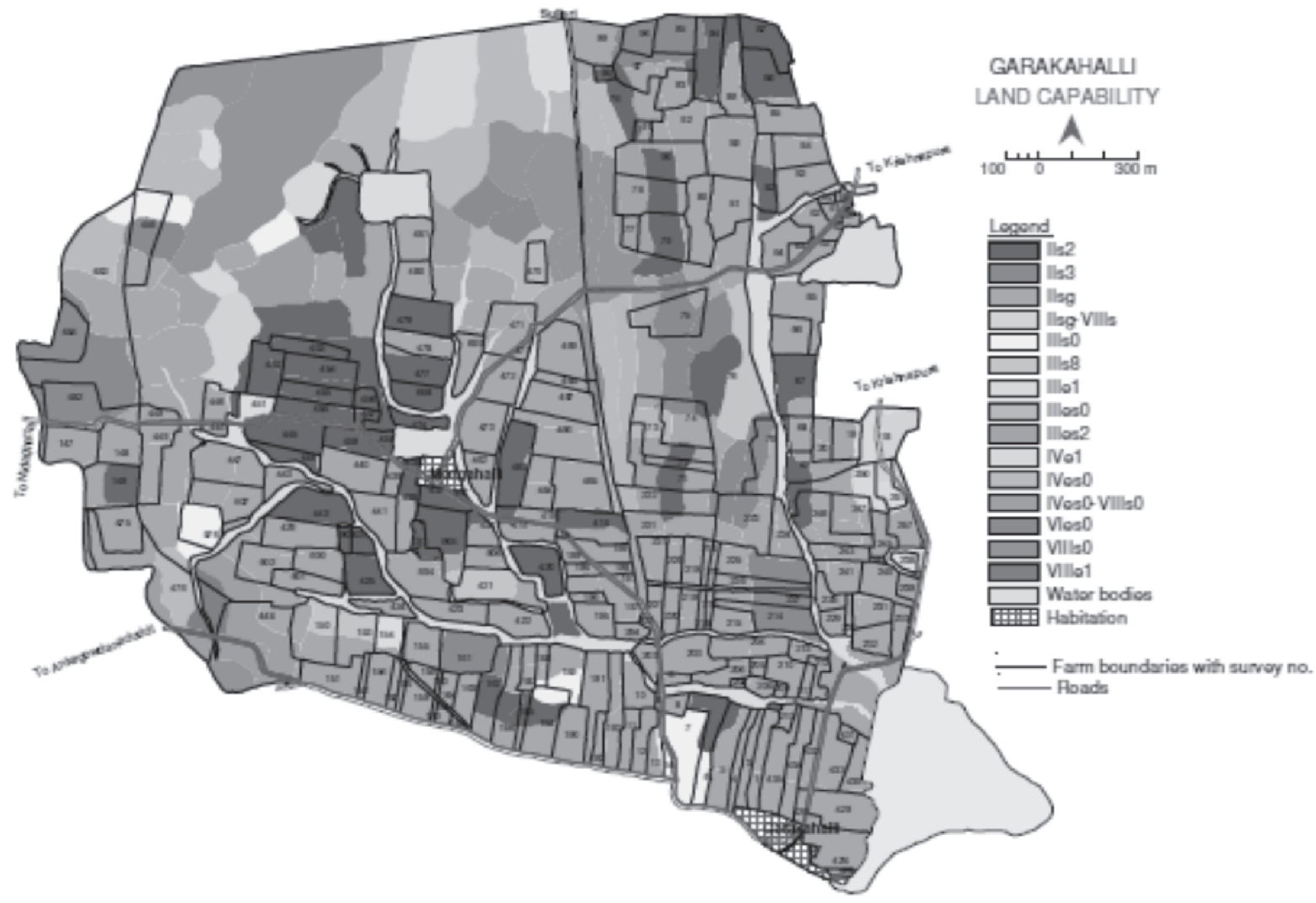

Fig. 4. Land capability subclass map of Garakahalli watershed

\section{Suitability of land for irrigation}

The land use and soil data were reclassified into four classes of land irrigability according to the FAO framework (FAO 1989). The land irrigability map (Fig. 5) shows that there is a possibility of irrigation in Garakahalli micro-watershed to an extent of 69.19 per cent of land as against the current irrigated land of 30 per cent. The clayey soils ( $>30 \%$ in sub-soils) in soil units of class-II lands and grouped as suitable for surface irrigation. The data shows that about 54 per cent of area is manageable for irrigation with levelling. The study recommended that drip irrigation is a better choice for more than 14 per cent of irrigable area than surface irrigation in rugged topography areas. Climatic conditions in the watershed show that area receives a mean annual rainfall of $821.0 \mathrm{~mm}$ with bimodal distribution and PET of $1496 \mathrm{~mm}$. The length of the main crop growing season is 120 to 150 days with probability of the growing season starts from the 33rd, 37th and 38th weeks. The end of the growing season is $46^{\text {th }}$ to the $51^{\text {st }}$ week with maximum probability of 18.52 per cent. The monthly rainfall and potential evapotranspiration indicates that rainfall is larger than potential evaporation during the rainy season. This suggests that there is no need of irrigation during the rainy season. However, supplementary irrigation may be necessary in case of unexpected dry spells and droughts. From the IMD data, it is estimated that reference crop evapotranspiration (ET) ranges between 5.44 and $4.32 \mathrm{~mm}$ day $^{-1}$ for the growing season from June to September. The net irrigation requirement (NIR) over the growing period may vary from 600 to $1000 \mathrm{~mm}^{-1}$ year $^{-1}$ depending upon the nature of crop grown. 


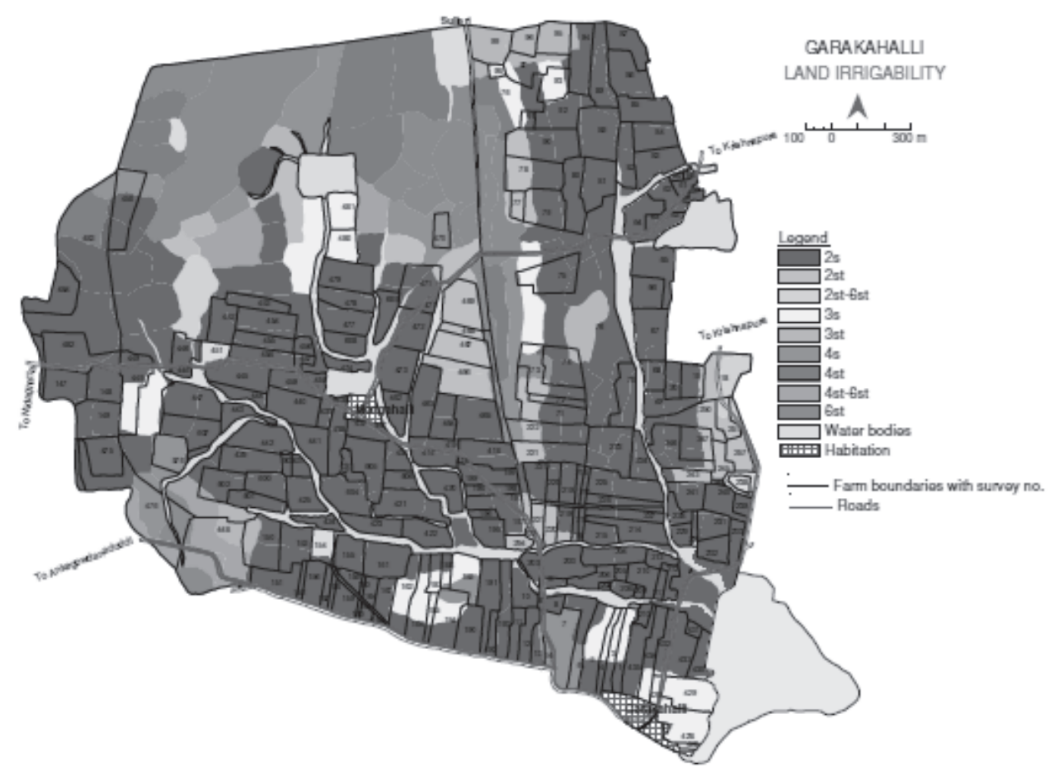

Fig. 5. Land irrigability subclasses map

\section{References}

FAO (1989). FAO Guidelines for designing and evaluating surface irrigation systems (FAO irrigation and drainage paper).Via delle Terme di Caracalla, 00100, Rome, Italy.

Jackson, M.L. (1973). Soil Chemical Analysis. Prentice Hall of India Private Limited, New Delhi. p,485. Klingebiel, A.A., and Montgomery, P.R. (1966). Land capability classification. Agric. Handbook 210, SCS, USDA, Washington D.C.
Mani, Bhushan., and Roy, L.B. (2018). Soil and land irrigability classification for soils of Bhagwanpur distributary of Gandak irrigation scheme in Bihar, India - A Case Study. Journal of Advanced Research in Dynamical \& Control Systems 10, 864 : 873.

Sehgal, J. L. (1996). Pedology - Concepts and Application, Kalyani Publishers, New Delhi, pp.1-488.

Soil Survey Staff (2014). 'Keys to soil Taxonomy',.12 edition. USDA/NRCS. Washington, D.C.

Received: January, 2018 Accepted: May,2018 